\title{
The Effect of Social Justice in Self-Efficacy Development of Organizations and Institutions Employees
}

\author{
Mohammad Hosseinkhani ${ }^{1}$ \& Qurban Giyaove ${ }^{1}$ \\ ${ }^{1}$ Social philosophia in Tajikistan University, Tajikistan \\ Correspondence: Mohammad Hosseinkhani, Social philosophia in Tajikistan University, Tajikistan. E-mail: \\ gama.epage@gmail.com
}

Received: May 11, 2015 Accepted: August 17, 2015 Online Published: August 26, 2015

doi:10.5539/ass.v11n22p247

URL: http://dx.doi.org/10.5539/ass.v11n22p247

\begin{abstract}
Self-Efficacy is one of the factors of progress in today societies, as the efforts of human resources have a deep connection with their Self-Efficacy. The aim of this study is to investigate the effect of justice dimensions in the creation and enhancement of the specified sample Self-Efficacy. Data gathering tool of this study is a structured questionnaire. The statistical population of the research is all employees of Metro Operation Company. The findings of this study indicate that there is a significant relationship between two mentioned concepts, i.e. the higher justice and its dimensions such as distributive, procedural and interactional justice within organizations we have, the higher self-efficacy exist among employees. Therefore, considering strategies to increase high self-efficacy and to lower the distribution difference between official and corporative resources in current societies is essential.
\end{abstract}

Keywords: social justice, distributive justice, procedural justice, interactional justice, organizations and institutions

\section{Introduction}

According to the organizations and institutions position in the individual's modern life, it is said that today's society is an organizational community, because most of the relations in the society is resolved and followed by referring to the organizations. The importance of the organizations and institutions functions reveal more when self-efficacy has a great impact on the performance of employees.

Albert Bandura, who first proposed the concept of self-efficacy, believes that self-efficacy is the most important psychological mechanism to influence the environment, and without getting self-efficacy and creating favorable effects and preventing adverse effects, people have little incentive to act, it means that belief into action is more important than the act itself. Belief in the power of creating desired effects is the infrastructure of any change in the human being (Bandura, 2000). In the psychological literatures, self-efficacy has been also translated as a self-efficacy and self-sufficiency that mentions its abilities for successful performance of the tasks and duties (Gholipour, 2007).

Researchers distinguish specific and general self-efficacy that general self-efficacy refers to beliefs of people about successful performance of tasks in different situations. But specific self-efficacy refers to the belief of successful performance in the specialized tasks. Bandura believed that self-efficacy implies on the specific task in a specific position, and is a context based feature (Cervone, 1997; Bandura, 1997). But the general self-efficacy is constant over time and in different situations and is like a personality traits (Edan \& Zuk, 1995). In this study, the general self-efficacy is considered by the researcher.

\subsection{The Concept of Justice and Its Dimensions}

Distributive justice: Distributive justice is the justice that determines how the costs and benefits should be distributive among the population. In other words, the purpose of distributive justice is that how social charity and benefits should be distributive to have a fair social relationship network and thus have justice driven society (Rawls, 1971). Distributive justice will get one of the following four forms in the writings of various philosophers and thinkers: distribution of merit, distribution in fairness, distribution according to need and distribution based on the principle of equity.

Procedural justice: In the past two decades, considerable researches have been done in the name of procedural 
justice. This new school of thought does not ruffle the primary focus on equity subjects, but also provides a new perspective on the issues of fairness at work. (Greenberg \& Fuljer, 1985) are taken procedural justice into account as "the perceived fairness of procedures used in making decisions".

The primary focus of procedural justice in organizational behavior and human resource management is the used practices to resolve disputes in the workplace. Then, researchers have developed their attentions to procedural justice issues related to diversity of workplace issues, such as personnel selection, allocation of rewards, performance assessment procedures, law and order, reward systems, and participatory decision-making systems. It is important during the procedural justice, especially as the standard for managerial decision making.

Interactional justice: Vast majority of researches on the theoretical reasoning of fairness in the organizations dedicated to the procedural and interactional justices. In more than the past decade, theorists distinguished the procedural justice that refers to the bureaucratic systems in which decide about individuals and interactional justice which should be performed with quality and interactions of individuals, as the people who are related; "The concern about the fairness of interpersonal communication, represents a set of issues that we are dealing with it as interactional justice." Through the interactional justice, we suggest that the individuals become sensitive to the quality of interpersonal behavior that will be received during the establishing organizational procedures. How a manager broadcasts the bad news on the new organizational policies that may have a great impact on the employee's perceptions about fairness as the nature of news and perceived equity of approved news.

Self-efficacy: One of the main aspects of the personality of individual is self-efficacy that provides a significant impact on the development of human personality. Acceptance and understanding of its features and relying on them mean as the self-efficacy. Achieving self-efficacy is the sign of accepting all the aspects of its existence, whether good or bad, and accepting the power and forces that a person need to do the work, to reach the goal or whatever else.

Self-efficacy is closely related to two other factors that are skills and abilities of the person and the person's self-esteem - so that the more individual abilities and skills increase, personality is get more easier and better understanding, as a result it will has a deeper impact on people's self-efficacy. Self-efficacy is also strengthening the self-esteem. In other words, self-esteem is defined as the value that the self-esteem information (self-efficacy) has for the person and has been caused from the individual beliefs of all his traits and characteristics. The self-efficacy also directly affects selection, motivation, perseverance, and mental patterns and vulnerability against stress (Bandura, 1993).

\section{Background}

Muslim philosophers have worked on social justice such as Ibn Khaldun (1957), Ibn Sina (2008) and al-Farabi (2004) notes. Previous researches on the concept of justice suggest that the concept has two-dimensions; the dimensions are distributive justice and interactional justice, which relates both to an independent dimension of Justice (Greenberge, 1990; Lind \& Taylor, 1988). While the investigation is complete, three-dimensional model of justice was proposed under Justice and the majority of researches that have focused on justice emphasized these three dimensions.

The distributive justice concerned to justice perceptions (fairness) to allocate resources by the organization. This kind of justice emphasized outputs (e.g. increased salaries, incentive legislation, assessment scores). Sources related to distributive justice are equity of Adams (1965), which is related to the perception of justice (fairness) towards the received ones. Distributive justice was the first justice concept that is studied by social psychologists. On the basis of Adams (1965) distributive justice can be defined as a perceived fairness of an individual's received in the social exchanges. Received ones may be material or spiritual. According to his researches, the people understand the fairness by the comparison of data and estimates, as well as the comparison of its relation with the standards which they have been received according to it. Procedural justice relates to perception of justice (fairness) to procedures used to consider the decision. This type of justice emphasizes the work procedures (such as how to upgrade or how to increase the salary): means that procedural justice refers to quality and fairness in the relations between the employee and the supervisor.

Research topic is one of the issues that most attentions have paid to it. Arizi studied the factors that are associated with justice in a research with the title of social justice approaches among teachers' of Isfahan. The study proved that egalitarianism represents equal access to core services and equal treatment with all individuals and equal distribution of wealth has a significant relationship with the social orientation, motivation, development and distributive justice. This study was conducted among 150 high school teachers of Isfahan (Arizi, 1383). 
Sharifzadegan in the research study of Rawls and Kant ideas has shown that distribution strategies are effective in solving the issues of social justice (Sharifzadegan, 1386). Perceiving justice effects on many behavioral factors and people's attitudes. Colquitt (2001) believes that positive perceptions about organizational procedures and processes results the increment of confidence level of in the organization. Greenberg (2002) also believes that the theft in the workplace is the reaction to injustice. He argues that the tolerance of people and teaching ethics to them is affected this reaction. Some researchers have noted that culture and environment of the institution, is as the environmental factors that could affect the content of education. He considered the level and type of contacts with teachers and students, with the hardware surrounding environment and also with together as the social and environmental factors that have a significant positive correlation with student satisfaction. According to description of above, the following hypothesis is:

- There is a significant and positive relationship between distributive justice and self-efficacy in the organizational institutions.

- There is a significant and positive relationship between procedural justice and self-efficacy in organizational institutions.

- There is a significant and positive relationship between interactional justice and self-efficacy in the organizational institutions.

- There is a significant and positive relationship between justice and self-efficacy in the organizational institutions.

Also, by considering the relationship between justice and self-efficacy and the hypothesis of this research, a conceptual model is drawn as below.

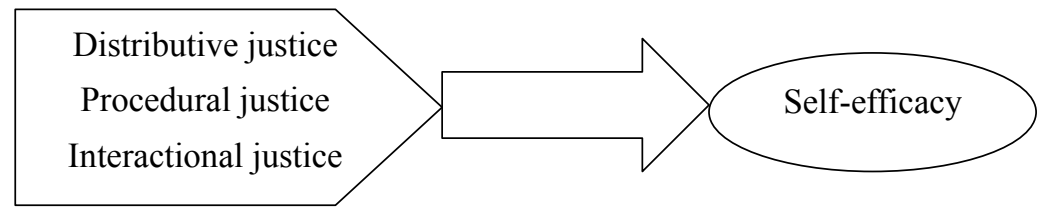

Figure 1. Conceptual diagram of self-efficacy and justice dimensions

\section{Research Methods}

\subsection{Statistical Population of the Study}

Statistical population and sample: The statistical study population is consisted of permanent and corporative staff of the Metro Operation Company and the distinction between these two groups is because that the distribution and allocation of rewards, salaries and wages is very different in them, and distribution of responsibilities and work rate among these two groups is also very different. For this reason, the justice discussion will be more imported. Statistical sample is included 448 of people from both groups that 237 of them were female and 211 were male. In this study, the variables of distributive, procedural and interactional justice were considered independent variables and self-efficacy variable was considered the dependent one.

A measure of the reliability and validity: for measuring general self-efficacy, the scale of Chen et al. (2001) is used, and the questions of 1 to 8 are intended in the questionnaire. To measure the dimensions of distributive justice the scale Kahn (2013) was used and the questions of 9 to 16 are considered. For procedural justice the questions 17 to 19 , and for interactional justice, questions 20 to 22 are considered. All options are in the five options of Likert scale options as follows:

Strongly agree (5) $\quad$ Agree (4) No idea (3) Disagree (2) strongly disagree (1)

In designing the questionnaire the required accuracy has performed so the questions have enough simplicity and clarity. To determine the reliability, the initial questionnaire was consisted of 22 questions that 8 questions were for self-efficacy and 14 questions for the three dimensions of justice (8 questions was designed for distributive justice and 4 questions for procedural justice). After general analyzing, self-efficacy factor structure was designed. The results of general analysis on questions of social justice were also showed three factors. Cronbach's alpha for scale self-efficacy is $86 \%$, for three-dimensional model of justice is $91 \%$ and total validity of scale with 22 questions is 0.8437 that indicates the reliability of research. To test the validity of the questions the reliability factor was also used. To assess the questionnaire content validity, the opinions of professionals, professors and experts specialists were used. At this stage the necessary corrections were performed by through various interviews and getting opinions of mentioned people, and thus we ensured that the questionnaire 
measures the desired properties of the authors.

Factorial Reliability test of questionnaire was also performed by confirmatory factorial analysis and LISREL 8.53software. Confirmatory factor analysis results for both self-efficacy and social justice scales 2 have been identified in Table 1 and.

Table 1. Measurement of the self-efficacy

\begin{tabular}{llll}
\hline Number & Questions of self-efficacy scale & T-value & Standard coefficient \\
\hline $\mathbf{1}$ & I can reach many of the goals I set for myself, & 6.35 & 0.71 \\
$\mathbf{2}$ & In facing with difficult tasks, I'm sure about doing them. & 1.71 & 0.47 \\
$\mathbf{3}$ & Overall, I think I can get the results that are important to me & 4.18 & 0.68 \\
$\mathbf{4}$ & I believe I can reach to what I've focused on & 3.91 & 0.46 \\
$\mathbf{5}$ & I am able to successfully overcome many of my problems. & 3.91 & 0.36 \\
$\mathbf{6}$ & I am confident that I can do many tasks better than others. & 4.92 & 0.69 \\
$\mathbf{7}$ & I can do many tasks better than others & 8.18 & 0.87 \\
$\mathbf{8}$ & Even when things are tough, I can well afford them & 6.39 & 0.62 \\
\hline
\end{tabular}

So to confirm the Confirmatory factor analysis, it should first have good fitting indices and second, its T-value must have a significant value. According to the results of the table, all T-values were significant.

Table 2. The measurement model of social justice

\begin{tabular}{|c|c|c|c|c|}
\hline Number & Questions of three-dimensional justice scale & dimensions & T-value & $\begin{array}{l}\text { Standard } \\
\text { coefficient }\end{array}$ \\
\hline 9 & $\begin{array}{l}\text { Based on experiences, I feel that rewards are distributed } \\
\text { fairly. }\end{array}$ & Distributive & 6.16 & 0.26 \\
\hline 10 & $\begin{array}{l}\text { Given the responsibilities I feel that rewards are } \\
\text { distributed fairly. }\end{array}$ & Distributive & 4.18 & 0.28 \\
\hline 11 & $\begin{array}{l}\text { According to the working pressure I feel that rewards } \\
\text { are distributed fairly. }\end{array}$ & Distributive & 4.55 & 0.29 \\
\hline 12 & $\begin{array}{l}\text { According to the sense of duty, I feel that rewards are } \\
\text { distributed fairly. }\end{array}$ & Distributive & 4.78 & 0.27 \\
\hline 13 & $\begin{array}{l}\text { Due to the amount of my effort if I feel that rewards are } \\
\text { distributed fairly. }\end{array}$ & Distributive & 5.26 & 0.25 \\
\hline 14 & The amount of work that has fallen to me is fair. & Distributive & 5.86 & 0.24 \\
\hline 15 & In total the amount of my responsibility and duty is fair. & Distributive & 6.10 & 0.27 \\
\hline 16 & $\begin{array}{l}\text { According to the work circumstances, the expectation to } \\
\text { do all the required functionality is unfair. }\end{array}$ & Distributive & 6.8 & 0.31 \\
\hline 17 & The standards of this organization to promote are fair. & procedural & 4.26 & 0.35 \\
\hline 18 & $\begin{array}{l}\text { According to the work circumstances, the expectation to } \\
\text { do all the required functionality is unfair. }\end{array}$ & procedural & 4.12 & 0.30 \\
\hline 19 & $\begin{array}{l}\text { Decisions about academic staff (or teachers) have run } \\
\text { identically. }\end{array}$ & procedural & 3.98 & 0.24 \\
\hline 20 & $\begin{array}{l}\text { Those who work with them in the organization have } \\
\text { dealt with me fairly. }\end{array}$ & Interactional & 3.11 & 0.18 \\
\hline 21 & $\begin{array}{l}\text { Those who work with me in the organization are treat } \\
\text { me honestly and ethical. }\end{array}$ & Interactional & 4.76 & 0.27 \\
\hline 22 & $\begin{array}{l}\text { Those who work with me in the organization behave } \\
\text { cheerfully. }\end{array}$ & Interactional & 6.21 & 0.33 \\
\hline
\end{tabular}

The results of the measurement model of social justice also show that this model is an appropriate model and reliability and validity of the questionnaire is high. Statistical test results by the Pearson correlation method 
between the self-efficacy and distributive justice is $(0.453)$ and between the self-efficacy and procedural justice is $(0.548)$ and between self-efficacy and interactional justice is $(0.167)$. Obtained Pearson's correlation between distributive justice and procedural justice respectively is $(0.502$ and 0.487$)$ and between distributive and interactional justice is $(0.362$ and 0.391$)$. Based on conducted tests there is a significant and positive correlation between distributive justice, procedural justice and interactional justice and self-efficacy variables.

\section{Results and Analysis}

Average (2.18) of self-efficacy among corporative employees (unofficial) is less than the average (2.54) of self-efficacy among official employees and the total average (2.36) of self- efficacy and " $\mathrm{t}$ " test indicates the low index of self-efficacy in all the subjects of this research.

Average (2.16) of distributive justice among unofficial employees is less than average (3.34) of distributive justice among official employees. The total average (2.64) of distributive justice demonstrated the low perception index of distributive justice between subjects of this research. Similarly, the average (2.24) of procedural justice among unofficial employees is less than the average (2.73) of procedural justice among official employees, while the total average of procedural justice demonstrated low procedural justice index in the subjects of this study. Average (2.17) of interactional justice among unofficial employees is less than average (3.57) of interactional justice among official employees but the total average (2.51) of interactional justice demonstrated the low index of interactional justice in subjects of this research.

In connection to rankings of each factors associated with self-efficacy, the Friedman test was used. SPSS output of significant test is $(\mathrm{P}=0.000)$ and is less than a significant standard level $(5 \%)$. Thus, we can say that associated factors with the self-efficacy do not have the same ranks. As can be seen Table 3, the highest ranking is for procedural justice and the lowest one is for interactional justice of the organizational institutions.

Table 3. Average ranks in the Friedman test

\begin{tabular}{lll}
\hline Dimension & Range & Quality \\
\hline Distributive justice & $\mathrm{N}=448$ & 81.3 \\
Procedural justice & Chi-Square $=642.012$ & 26.3 \\
Interactional justice & d.f $=4$ & 16.3 \\
\hline
\end{tabular}

\section{Conclusion and Discussion}

As described, institutions and organizations are the oldest institutions in the human society. Hence the existence of social justice and its dimensions in the institutions and organizations is essential and has a direct impact on their performances.

Based on the results of the study, average of justice in all three dimensions of distributive justice, procedural justice and interactional justice is low in the study group, especially in the group of corporative employees (unofficial) this indicates that employees feel low justice in their rewards, salaries and benefits, social procedures and instructions, and interactions. And continuation of this situation to promote organization level and provision of services may face difficulties. According to these findings, it is recommended that the organization provide self-efficacy and self-awareness skills as well as sociability and reviewing strategies of equitable distribution.

\section{References}

Adams, J. S. (1965). Inequity in social exchange. In L. Berkowitz (Ed.), Advances in experimental social psychology (Vol. 2, pp. 267-299). New York: Academic Press. http://dx.doi.org/10.1016/s0065-2601 (08)60108-2

Bandura, A. (1986). Social Foundations of Thought and Action. Englewood Cliffs, N.J: Prentice Hall.

Bandura, A. (1993). Perceived self-efficacy in cognitive development and functioning. Educational psychologist, 28(2), 117-148. http://dx.doi.org/10.1207/s15326985ep2802_3

Bandura, A. (2000). Cultivate self-efficacy for personal and organizational effectiveness, In E. A. Locke (Ed.), Handbook of principles of organization behavior (pp. 120-136), Oxford, UK: Blackwell.

Broad, H. R. (2004). Teachers' approaches to social justice in the city of Isfahan. College of Social Welfare, 1(13), $17-28$.

Bulent, S. (2005). The combined effects of trust and employee identification on intention to quit. Gebze: Institute 
of Technology.

Cervone, D. (1997). Social-cognitive mechanisms and personality coherence: Self-knowledge, situational beliefs, and cross-situational coherence in perceived self-efficacy. Psychological Science, 8, 43-50. http://dx.doi. org/10.1111/j.1467-9280.1997.tb00542.x

Chen, G., Gully, S. M., \& Eden, D. (2001). Validation of a new general self-efficacy scale. Organizational research methods, 4(1), 62-83. http://dx.doi.org/10.1177/109442810141004

Colquitt, J. A. (2001). On the dimensionality of organizational justice: a construct validation of a measure. Journal of applied psychology, 86(3), 386. http://dx.doi.org/10.1037/0021-9010.86.3.386

Eden, D., \& Zuk, Y. (1995). Seasickness as a self-fulfilling prophecy: Raising self-efficiency to boost performance at sea. Journal of Applied Psychology, 80, 628-635. http://dx.doi.org/10.1037/0021-9010. 80.5 .628

Farabi. (2004). Ehsaol Oloum, Trans. By Khadiv, H., Tehran: Elmi \& Farhangi Pub.

Gholipour, A. (2005). Organizations, institutional approach to organization and management. Tehran: Samt Pub.

Greenberg, J. (1990). Organizational justice: Yesterday, today, and tomorrow. Journal of Management, 16, 399-432. http://dx.doi.org/10.1177/014920639001600208

Greenberg, J., \& Lind, E. A. (2000). In C. L. Cooper, \& E. A. Locke (Eds.), The pursuit of organizational justice: From conceptualization to implication to application.

Khaldun, A. A. A. W. I. (1957). Muqaddimat Ibn Khaldun.

Khan, A. K., Quratulain, S., \& Crawshaw, J. R. (2013). The mediating role of discrete emotions in the relationship between injustice and counterproductive work behaviors: A study in Pakistan. Journal of business and psychology, 28(1), 49-61. http://dx.doi.org/10.1007/s10869-012-9269-2

Mager, R. F. (1992). No self-efficacy, no performance. Training, 29(4), 32-36.

Maslow, A. (1954/1987). Motivation and personality (3rd rev. ed.). New York: Harper \& Row.

Rawls, J. (1971). A theory of justice. Cambridge, MA: Harvard University Press.

Sina, A. A. (2008). Mantiq Al Mashreqin, Ghom: Esmat Pub.

\section{Copyrights}

Copyright for this article is retained by the author(s), with first publication rights granted to the journal.

This is an open-access article distributed under the terms and conditions of the Creative Commons Attribution license (http://creativecommons.org/licenses/by/3.0/). 